\title{
Nuclear transfer reprogramming does not improve the low developmental potency of embryonic stem cells induced by long-term culture
}

\author{
T Amano ${ }^{1}$, M Gertsenstein $^{2}$, A Nagy ${ }^{2}$, H Kurihara $^{3}$ and H Suzuki ${ }^{1,4}$ \\ ${ }^{1}$ Department of Developmental and Medical Technology, Graduate School of Medicine, The University of Tokyo, \\ 7-3-1 Hongo, Bunkyo-ku, Tokyo 113-0033, Japan, ${ }^{2}$ Samuel Lunenfeld Research Institute, Mount Sinai Hospital, 600 \\ University Avenue, Toronto, Ontario M5G 1X5, Canada, ${ }^{3}$ Department of Physiological and Metabolism, Graduate \\ School of Medicine, The University of Tokyo, Tokyo, Japan and ${ }^{4}$ National Research Center for Protozoan Diseases, \\ Obihiro University of Agriculture and Veterinary Medicine, Obihiro 080-8555, Japan
}

Correspondence should be addressed to H Suzuki; Email: hisuzuki@obihiro.ac.jp

\begin{abstract}
Epigenetic states of embryonic stem (ES) cells are easily altered by long-term cultivation and lose their developmental potential. To rescue this reduced developmental capacity, nuclear transfer (NT) of ES cells was carried out, and original ES and ES cells from cloned blastocysts (ntES) cells established after NT were compared with in vitro differentiation ability and developmental potential by embryoid body formation and tetraploid aggregation respectively. In the establishment of ntES cell lines, the oocytes fused with the ES cell were activated, and further cultured to cloned blastocysts. When in vitro differentiation ability was examined between original and ntES cell lines derived from ES cells with extensive passages (ES-ep), the day of appearance of simple embryoid body, cystic embryoid body, and spontaneous beating was almost similar. The developmental rates of ES-ep cells, that aggregated with tetraploid embryos to term, ranged from 3 to $6 \%$. Moreover, the majority of live pups died soon after birth. In the ntES cell lines derived from ES-ep cells, developmental rates ranged from 0 to $5 \%$. Those pups also died soon after birth, similar to the ES-ep-derived pups. These results suggest that profound epigenetic modifications of ES cells were retained in the re-established cell lines by NT.

Reproduction (2006) 132 257-263
\end{abstract}

\section{Introduction}

Embryonic stem (ES) cells can develop into many tissues if they are returned to the embryonic environment (Robertson 1987). Due to these characteristics, the ES cells have been utilized for gene targeting. Moreover, Nagy et al. developed a model of ES cell-derived mice by aggregation of tetraploid embryos (Nagy et al. 1990, 1993, Ueda et al. 1995). In particular, when the gene highly expressed in trophoblast cells of the postimplantation embryo is targeted, production of ES derived-mice by 'tetraploid rescue' seems to be useful for analyzing the genetic function (Tanaka et al. 1997). However, the majority of the completely ES-derived mice died soon after birth (Nagy et al. 1990, 1993), because the quality of ES cells including the number of chromosomes and the epigenetic state is rapidly lost during in vitro culture. Profound epigenetic alterations of the genome may negatively affect the pluripotency of ES cells (Dean et al.
1998). Therefore, it is impossible to use the ES cell line for a long term for generating mice, although they can be cultured in vitro semi-permanently.

Recent studies have shown that it is possible to transfer the nucleus from an ES cell to the enucleated oocyte and achieve embryonic development under the control of the transferred nuclei. These findings suggest that the epigenetic state of donor nuclei is reprogrammed in the enucleated oocyte. However, many researchers have also shown that the majority of the pups obtained after the transfer of cloned embryos die soon after birth (Wakayama et al. 1999, Rideout et al. 2000, Amano et al. 2001, Eggan et al. 2001). This suggests that ES cells already had profound epigenetic modification during in vitro culture. Nevertheless, the nuclear-transferred embryos from these ES cells have at least the potential for early embryonic development. Recently, it has been shown that ES cell lines can be established from cloned blastocysts (ntES cell) with the ability to differentiate 
both in in vitro and in vivo conditions (Munsie et al. 2000, Wakayama et al. 2001).

The ES cells also are able to differentiate in vitro into several lineages. The simplest technique is the formation of an embryoid body (EB), which includes ectodermal, endodermal, and mesodermal lineages. In early studies, to estimate the potential of a newly established ES cell line, in vitro formation of EB was frequently performed by suspension culture (Robertson 1987). Moreover, it has been demonstrated that there is a relationship between the ability to differentiate into simple embryoid body (SEB) or cystic embryoid body (CEB) in vitro and the potential of germline transmission chimeric mice (Suzuki et al. 1997). Thus, the capacity for germline transmission of the ES cells can be estimated from the day of appearance of EBs in suspension culture.

In the present study, we examined whether low potential of ES cells with extensive passages (ES-ep) and hence with altered epigenetic status can be rescued by NT reprogramming.

\section{Materials and Methods}

\section{ES cell line and karyotype analysis}

The ES cell lines used in this study were YV1 and YC5 established by A Nagy (Hadjantonakis et al. 2002) and TT2 (Yagi et al. 1993), which were derived from genetically hybrid embryos. Chromosome spreads of these ES cells were prepared as described previously (Suzuki et al. 1997).

\section{In vitro differentiation}

After the treatment of ES cells with trypsin $(0.25 \%$; Sigma), single cell suspensions (500 cells/20 $\mu$ l drop) were cultured by the hanging drop method (Keller 1995) for 2 days in Dulbecco's modified Eagle's medium (DMEM) supplemented with $10 \%$ fetal bovine serum (Biowest Miami, FL, USA). The resulting ES cell aggregates were transferred into a bacteriological dish (10 cm; Nissui, Tokyo, Japan). These aggregates quickly delineated a layer of endoderm cells on their surface forming structures termed 'SEB'. When suspension culture was continued, SEB formed 'CEB'. These CEB were further cultured for several days to assess the spontaneous initiation of beating, suggesting that ES cells have differentiated to the mesodermal lineage. On the designated day for the appearance of SEB, CEB, or beating was determined by observing ten or more embryoid bodies per dish.

\section{Tetraploid aggregation}

ICR females (Clea, Tokyo, Japan) were superovulated by injection of equine chorionic gonadotropin (eCG)
(5 IU, serotropin; Teikokuzouki, Tokyo, Japan) followed by human chorionic gonadotropin (hCG) $48 \mathrm{~h}$ later (5 IU, gonadotropin Teikokuzouki). After the administration of hCG, females were mated with same strain males and two-cell stage embryos were recovered from the oviduct by flushing with M2 medium (Fulton \& Whittingham 1978). The recovered embryos were transferred to $0.3 \mathrm{M}$ mannitol solution and aligned automatically by alternating current pulse in a chamber comprising two wire electrodes mounted $1 \mathrm{~mm}$ apart on a glass slide (Nepagene, Chiba, Japan). Then, two direct current pulses of $140 \mathrm{~V} / \mathrm{mm}$ were given for $40 \mu$ s with a pulse generator (LF101; BEX, Tokyo, Japan). The fusion of two blastomeres occurred within $30 \mathrm{~min}$ and these fused embryos were considered to be tetraploids and cultured to the four-cell stage in a potassium simplex optimized medium (KSOM; Nagy et al. 1993) for $24 \mathrm{~h}$ at $37^{\circ} \mathrm{C}$ in $5 \% \mathrm{CO}_{2}$.

\section{Nuclear transfer (NT)}

The $\mathrm{F} 1 \mathrm{mice}(\mathrm{C} 57 \mathrm{BL} / 6 \mathrm{~N} \times \mathrm{C} 3 \mathrm{H} / \mathrm{HeN})$ (Clea) were used as oocyte donors throughout. Unfertilized eggs were collected from superovulated females $13.5-15 \mathrm{~h}$ after the hCG injection and freed from the cumulus oophorous by hyaluronidase (300 Units; Sigma) treatment. They were then transferred into the M2 medium containing $5 \mu \mathrm{g} / \mathrm{ml}$ cytochalasin B (Sigma) and mechanically enucleated for use as recipient cytoplasm. A single ES cell, synchronized at metaphase by $3 \mu \mathrm{g} / \mathrm{ml}$ of nocodazole (Sigma) treatment for $3 \mathrm{~h}$ (Amano et al. 2001), was fused with an enucleated oocyte by electrofusion, in which the condition was $120 \mathrm{~V} / \mathrm{mm}$ for $20 \mu$ s using an LF101 pulse generator manufactured by BEX. The oocytes fused with ES cells were then transferred into the KSOM medium supplemented with $5 \mu \mathrm{g} / \mathrm{ml}$ cytochalasin B for $1 \mathrm{~h}$ before activation. For activation, the fused oocytes were cultured in $\mathrm{Ca}^{2+}$-free KSOM supplemented with $10 \mathrm{mM} \mathrm{Sr}^{2+}$ (Sigma) for $5 \mathrm{~h}$. The activated oocytes were cultured in vitro to the blastocyst stage (ntBlastocyst) and transferred to recipient mothers.

\section{Establishment of ntES cell line}

ntBlastocysts developed in vitro were treated with acidic Tyrode's solution (IS Japan, Japan) to remove Saitama the zona pellucida and then cultured in DMEM medium for ES cell culture (ES-DMEM) on mouse embryonic fibroblasts (Munsie et al. 2000). To establish ES cell lines, inner cell mass outgrowths were mechanically dissociated in the presence of $0.25 \%$ trypsin and then re-plated on mouse embryonic fibroblasts in ES-DMEM (ntES cell lines). 


\section{Comet assay}

Each ES cell line $\left(1 \times 10^{5}\right.$ cells) was suspended in $50 \mu \mathrm{l}$ of PBS and then transferred to $500 \mu$ l low-melting temperature agarose (Comet assay kit; Trevigen, Gaithersburg, MD, USA). Seventy-five microliters agarose including ES cells were placed on a slide glass. After $10 \mathrm{~min}$, the ES cells were lysed by incubating the slides for $60 \mathrm{~min}$ in lysis buffer. The slides were then removed from the lysis solution, placed in alkaline solution for $60 \mathrm{~min}$, and then transferred to an electrophoresis unit. The unit was filled with fresh TBE buffer to a level $0.25 \mathrm{~cm}$ above the slides, and electrophoresis was conducted for $10 \mathrm{~min}$ at $1 \mathrm{~V} / \mathrm{cm}$ using an electrophoresis compact power supply. After electrophoresis, the slides were washed with $70 \%$ ethanol for $5 \mathrm{~min}$. Each dried slide was stained with SYBR Green (Trevigen).

\section{Recipient females and caesarean sections}

The blastocysts were transferred to each uterine horn of pseudopregnant females on 2.5 days postcoitum (dpc). The recipient mothers were killed on 18.5-19.5 dpc, and the pups were quickly removed from the uterus. These pups were placed under a warming light and respiration was observed. Surviving pups were fostered to lactating ICR mothers.

\section{Statistical analysis}

The data were analyzed using the $\chi^{2}$-method.

\section{Results}

The proportions of the 40 chromosomes of ES-Ip (Ip, $<10$ passages) and ES-ep (ep, over 40 passages) cell groups, as shown in Fig. 1, were 68\% (61/90; G4-Ip and 63/93; YV1-lp) and 53-61\% (41/77; YC5-ep, 50/85; TT2-ep, and 54/89; YV1-ep) respectively. These differences were not statistically significant. The comet assay did not detect any DNA damage, that is represented by an increase in DNA fragments that have migrated out of the cell nucleus in the form of a characteristic streak similar to the tail of a comet in any of the cell lines, indicating that the DNA of the ES cells had not fragmented during in vitro culture, even the passage number exceeded 40 (51-102 nucleus were examined).

Five ES cell lines were then aggregated with diploid or tetraploid embryos and transferred to recipient animals to assess their in vivo developmental ability. The proportion of live chimera pups ranged from 24 to
A (\%)

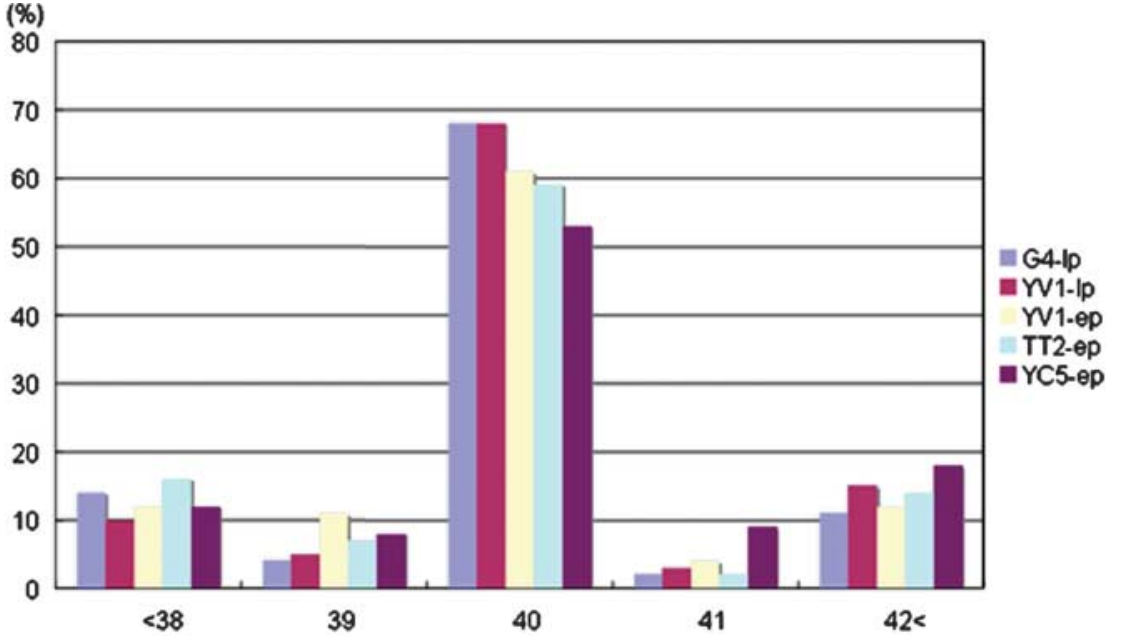

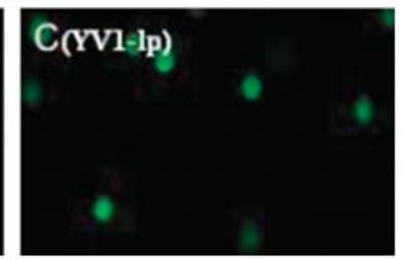

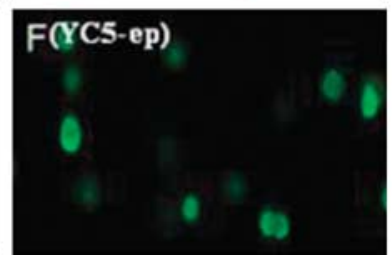

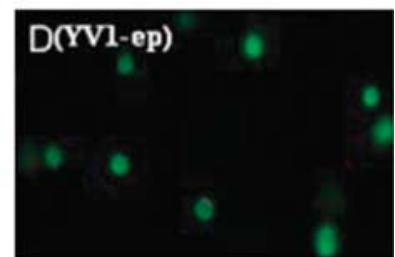

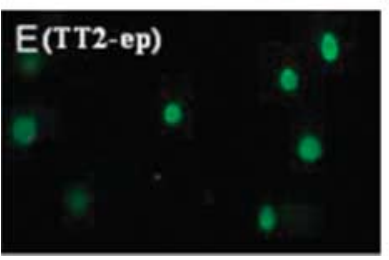

www.reproduction-online.org
Figure 1 Karyotype analysis and comet assay in ES cell lines. Four ES cell lines with (ES-ep) or without (ES-Ip) ES-ep were used. (A) All the cell lines were arrested in metaphase by adding colcemid $(0.1 \mu \mathrm{g} / \mathrm{ml}$ at final concentration) to the culture medium and the prepared cells were counted for chromosome number. (B-F) ES cells prepared by comet assay kit were subjected to electrophoresis and stained with SYBR Green. Green stained cells without the characteristic streak represent cells free from DNA damage. 
Table 1 In vivo developmental ability of diploid and tetraploid embryos aggregated with ES cells.

\begin{tabular}{|c|c|c|c|c|c|c|c|}
\hline ES cell line & $\begin{array}{l}\text { Genetic back- } \\
\text { ground of ES cell }\end{array}$ & $\begin{array}{c}\text { Type of } \\
\text { aggregationt }\end{array}$ & $\begin{array}{l}\text { No. of embryos } \\
\text { transferred }\end{array}$ & $\begin{array}{l}\text { No. of chimeras } \\
\text { or ES-mice } \\
\text { obtained }(\%) \neq\end{array}$ & $\begin{array}{c}\text { No. of respired } \\
\text { pups }(\%) \neq\end{array}$ & $\begin{array}{c}\text { No. of pups } \\
\text { surviving at } \\
\text { adulthood }(\%) \neq\end{array}$ & $\begin{array}{l}\text { No. of germline } \\
\text { mice }(\%) \neq\end{array}$ \\
\hline \multirow[t]{2}{*}{ G4-Ip } & \multirow[t]{2}{*}{ 129/B6 } & DA & 98 & $25(26)$ & $24(96)^{a}$ & $22(92)^{a}$ & $22(100)^{\mathrm{a}}$ \\
\hline & & TA & 303 & $58(19)^{\mathrm{a}}$ & $44(76)^{b}$ & $33(75)$ & $31(94)^{a}$ \\
\hline \multirow{2}{*}{ YV1-Ip } & \multirow[t]{2}{*}{ B6/129 } & DA & 59 & 19(32) & $19(100)^{\mathrm{a}}$ & $17(89)$ & $13(76)^{b}$ \\
\hline & & TA & 107 & $20(19)^{a}$ & $17(85)^{a, b}$ & 15(88) & $13(87)^{a, b}$ \\
\hline YV1-ep & B6/129 & DA & 1639 & $5(3)^{b}$ & $1(20)^{\mathrm{C}}$ & $0(0)^{b}$ & - \\
\hline \multirow{2}{*}{ TT2-ep } & \multirow{2}{*}{ B6/CBA } & DA & 62 & $15(24)$ & $15(100)^{\mathrm{a}}$ & $15(100)$ & $8(53)^{b}$ \\
\hline & & TA & 258 & $16(6)^{b}$ & $3(19)^{\mathrm{c}}$ & $3(100)$ & $2(67)^{b}$ \\
\hline \multirow[t]{2}{*}{ YC5-ep } & \multirow[t]{2}{*}{$129 / 129$} & DA & 63 & $17(27)$ & $13(76)^{b}$ & $11(85)$ & $7(64)^{b}$ \\
\hline & & TA & 144 & $5(3)^{b}$ & $1(20)^{\mathrm{c}}$ & $0(0)^{b}$ & - \\
\hline
\end{tabular}

Ip; Low passages, ep; Extensive passages; $†$, Diploid aggregation; TA, Tetraploid aggregation; ¥, Calculated from number of embryos transferred. Values with different superscripts in the same column differ significantly $(P<0.05)$.

$32 \%$ after diploid aggregation, as shown in Table 1. Moreover, the majority (more than $76 \%$ ) respired after caesarean section on $18.5 \mathrm{dpc}$ and survived to adulthood. The contribution of ES cells to the germline in the chimera ranged from 53 to $100 \%$. On the other hand, when ES cells were aggregated with tetraploid embryos, the production rates of the ES-derived mice were $19 \%$ for the ES-Ip cell lines (YV1-Ip and G4-Ip), and 3-6\% for the ES-ep cell lines (YC5-ep, TT2-ep, and YV1ep). Moreover, although $76 \%$ of the G4-Ip and $85 \%$ of the YV1-Ip ES-derived pups were immediately respired after caesarean section, approximately $80 \%$ of the pups from ES-ep cells did not exhibit breathing after birth, indicating the accumulation of profound epigenetic modifications in ES cell with extensive passages.

Electrofusion NT of these cell lines was carried out to strictly evaluate the developmental potential of ES-ep cells. The proportion of nuclear transferred oocytes ('cybrids') that developed into the blastocyst stage was $35-58 \%$. There were significant differences between

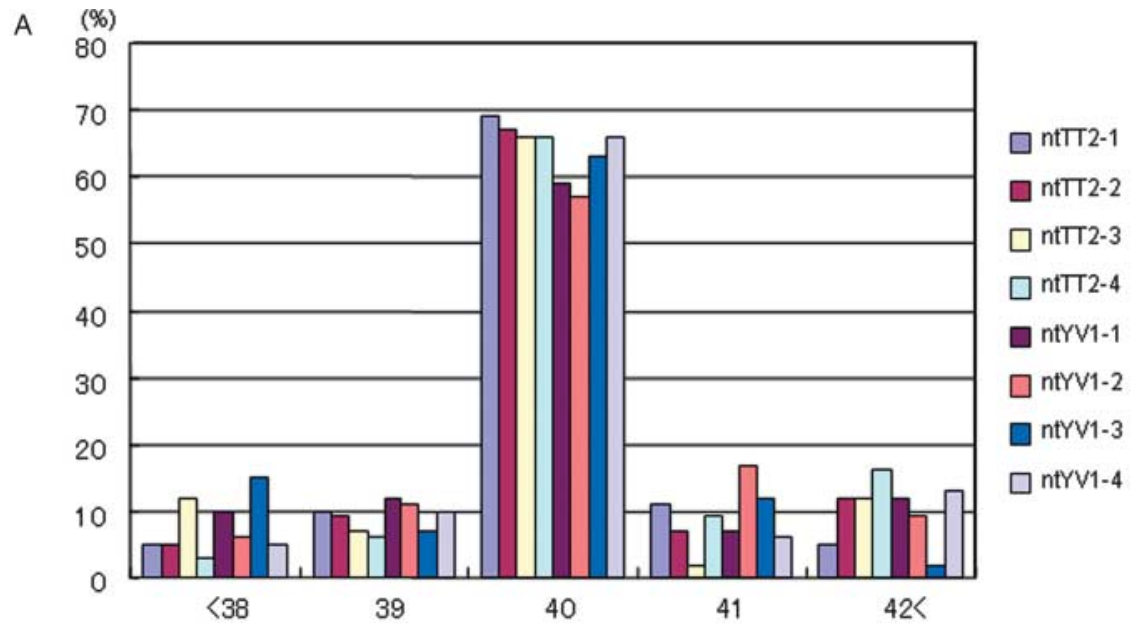

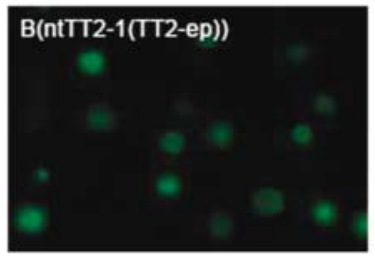
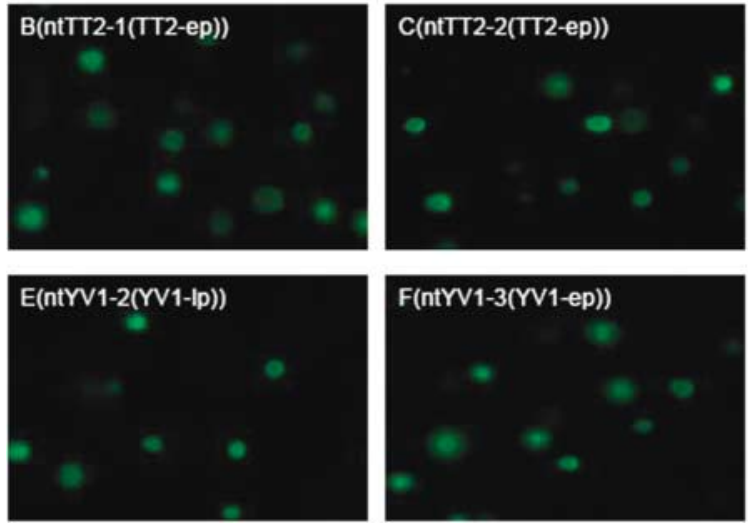
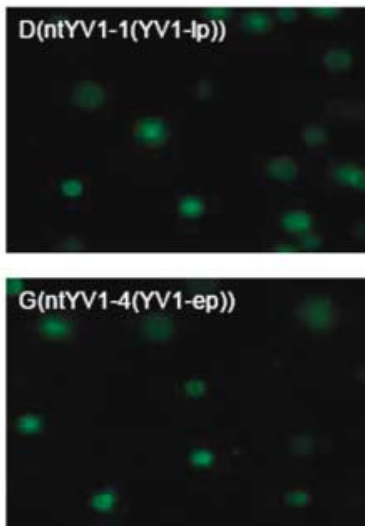

Figure 2 Karyotype analysis and comet assay of newly established ntES cell lines. (A-F) ntES cell lines were established from ES-ep and ES-Ip cells respectively. All the cell lines were subjected to comet assay at passage 5 .

Parentheses indicate the nuclear transfer (NT) donor. (G) All the ntES cell lines were arrested in metaphase by adding colcemid $(0.1 \mu \mathrm{g} / \mathrm{ml}$ at final concentration) to the culture medium and the prepared cells were counted for chromosome. 

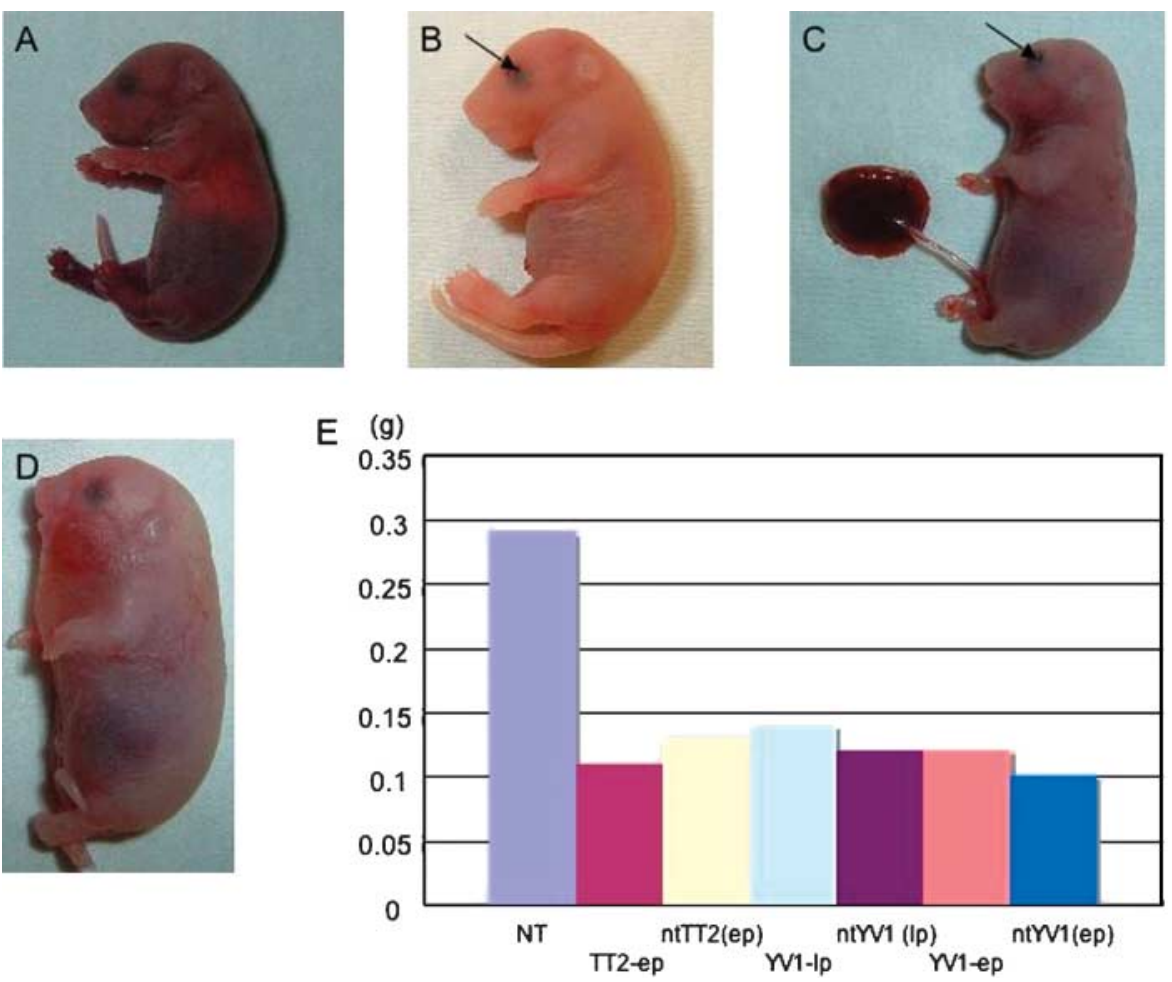

Figure 3 Morphological appearance of ES-derived pups and their placenta weight after tetraploid aggregation. (A) ES-derived pup from ES-lp cells. The majority of these pups were revived after caesarean section. (B-D) ntES-derived pups from ES-ep cells. All fetuses had abnormal phenotypes. The arrow shows the opened eyes. (E) Placenta weights were not significantly different among the tetraploid aggregation pups. Their weight was significantly lower than that of all the NT pups.

YV1-Ip and others for developmental potential to the blastocyst stage. When these blastocysts were transferred to recipient mothers, 25 live pups (6-8\%) were obtained from ES-Ip cell lines after caesarean section on $18.5 \mathrm{dpc}$, although the majority of them did not respire immediately and died within 30 min after birth. In contrast, in the ES-ep cell lines, live pups were not obtained after transfer of cloned embryos, although there were no significant differences in terms of developmental potential to the blastocyst stage compared with the ES-Ip cell lines. These results suggest that profound epigenetic modification had accumulated in ES-ep cells during long-term culture.
ntES cell lines were established from blastocysts derived from NT of TT2-ep, YV1-ep, and YV1-Ip ES cells. Of the 39, 26, and 37 ntblastocysts, eight cell lines were obtained in total. The efficiency of the isolation of ES cell lines ranged from 5 to $10 \%$ (Table 3). The in vitro stability of the ntES cells was examined by chromosome and comet assay (Fig. 2). The eight cell lines, which had a normal diploid chromosome constitution $(n=40)$, were $57-69 \%$ at passage 5 and the proportion was not different from the original ES cells. Moreover, no DNA damage was detected in any of the cell lines by comet assay.

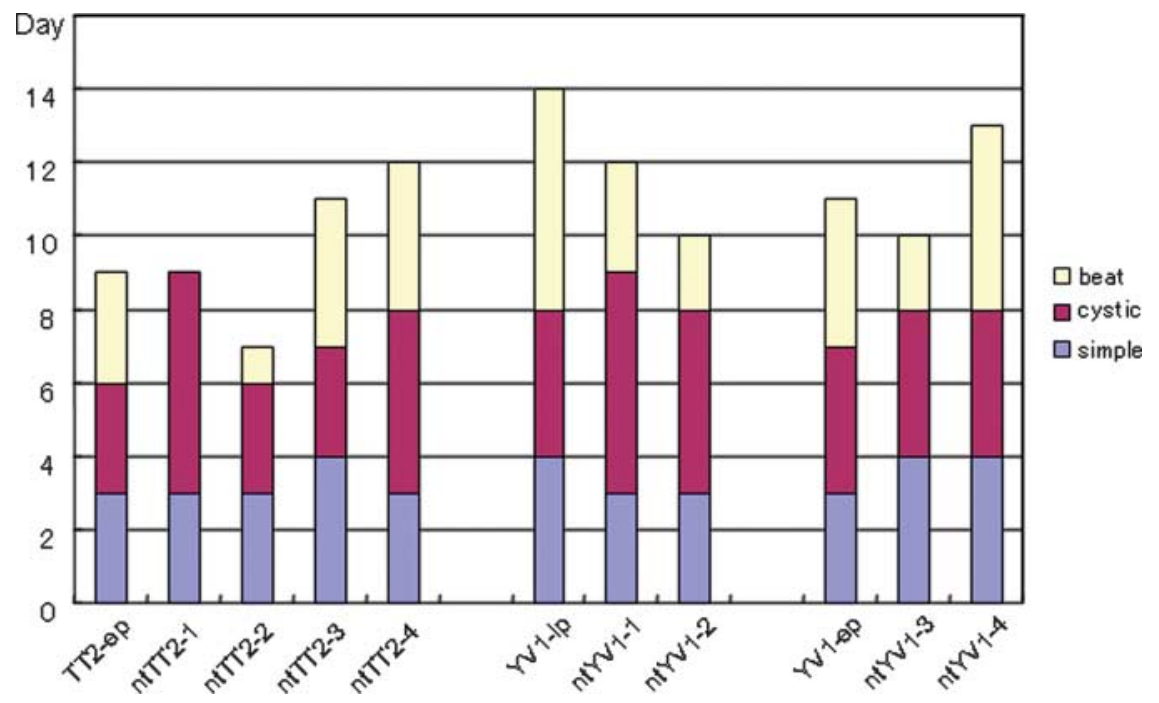

Figure 4 Appearance of simple embryoid body (SEB), cystic embryoid body (CEB), and initiation of spontaneous beating of cystic EB. Original ES cell lines (TT2-ep, YV1-lp, and YV1-ep ES cells) and ntES cell lines were examined for their in vitro differentiation ability. Single cell suspensions were cultured by the hanging drop method. The resulting ES cell aggregates were transferred into a bacteriological dish and cultured to form SEB and CEB. 
Table 2 Development potential of ES cells with or without extensive passage after nuclear transfer.

\begin{tabular}{|c|c|c|c|c|c|c|c|c|}
\hline ES cell line & $\begin{array}{c}\text { Genetic } \\
\text { background } \\
\text { of ES cells }\end{array}$ & $\begin{array}{l}\text { No. of oocytes } \\
\text { cultured }\end{array}$ & $\begin{array}{l}\text { No. of oocytes } \\
\text { developed to } 2 \\
\text { cell stage }(\%)^{1}\end{array}$ & $\begin{array}{c}\text { No. of oocytes } \\
\text { developed to } \\
\text { balstocysts }(\%)^{1}\end{array}$ & $\begin{array}{l}\text { No. of } \\
\text { blastocysts } \\
\text { transferred }\end{array}$ & $\begin{array}{c}\text { No. of } \\
\text { recovered live } \\
\text { pups }(\%)^{2}\end{array}$ & $\begin{array}{c}\text { No. of } \\
\text { resprired } \\
\text { pups }(\%)^{3}\end{array}$ & $\begin{array}{c}\text { No. of } \\
\text { surviving to } \\
\text { adulthood }(\%)^{4}\end{array}$ \\
\hline G4-Ip & 129/B6 & 185 & 181(98) & $108(58)^{a}$ & 83 & $7(8)$ & 2(29) & $2(100)^{\mathrm{C}}$ \\
\hline YV1-Ip & B6/129 & 891 & $874(98)$ & $312(35)^{b}$ & 290 & $18(6)$ & $6(33)$ & $3(50)^{d}$ \\
\hline YV1-ep & B6/129 & 278 & $268(96)$ & $141(53)^{a}$ & 135 & $0(0)$ & - & - \\
\hline TT2-ep & B6/CBA & 74 & 72(97) & $36(49)^{a}$ & 36 & $0(0)$ & - & - \\
\hline YC5-ep & $129 / 129$ & 349 & $337(97)$ & $183(52)^{a}$ & 106 & $0(0)$ & - & - \\
\hline
\end{tabular}

${ }^{1}$ Calculated from number of oocytes cultured.

${ }^{2}$ Calculated from number of balstocysts transferred.

${ }^{3}$ Claculated from number of recovered live pups.

${ }^{4}$ Calculated from number of respired pups.

Values with different superscripts in same column differ significantly $(P<0.05)$.

The ntES cells at passage 5 were aggregated with tetraploid embryos. When ntES from TT2 and YV1 ES-ep cells were used for tetraploid aggregation, ES-derived newborns were obtained at low efficiency $(0-5 \%)$, as shown in Table 4. Moreover, seven of the eight pups had opened eyes or edema (Fig. 3) and none were revived after birth. When ntYV1-2 ES cells from YV1 ES-lp cells were used for aggregation, the proportion of newborn (15\%) and revived pups (79\%) was higher than the original YV1-Ip ES cells. In contrast, ntYV1-1 ES cells showed low developmental potential after embryo transfer into the uterus of recipient females, indicating the accumulation of unexpected modifications during the establishment of ntES cell line. There were no significant differences in the placental weight of the pups between ES-ep and ES-Ip cells.

The in vitro differentiation ability was evaluated by EB formation including simple, cystic, and spontaneous beating initiation (Fig. 4). No correlation between ES-ep and ES-Ip cells for SEB, CEB, and beating initiation was observed. These results suggest that the developmental potential of ES cell was lost easily due to the accumulation of profound epigenetic modifications by long-term in vitro cultivation, and the developmental potential of ES could not be rescued by NT.

\section{Discussion}

Since ES cells easily accumulate epigenetic alterations during in vitro culture (Dean et al. 1998), their developmental potential to full term after tetraploid complementation or NT is rapidly lost. It has been reported that imprinted gene expression in ES cells is extremely unstable during maintenance in culture (Humpherys et al. 2001), and epigenetic alterations in imprinted genes in ES cells persist to later developmental stages, and are associated with aberrant phenotypes (Dean et al. 1998). Our data, as shown in Tables 1 and 2, coincided with these previous reports and also suggested that the developmental potential of ES-ep cells into postnatal development was suppressed by the accumulation of profound epigenetic modifications during long-term culture, even if ES cell lines were derived from hybrid genetic background as previously described (Eggan et al. 2001).

We expected to rescue the low developmental potential of ES-ep cells by establishing ntES cell lines

Table 3 Establishment of ntES cell lines after nuclear transfer of ES cell.

\begin{tabular}{lccc}
\hline Nucleus donor & No. of reconstructed oocytes & No. of developed to blastocysts (\%) & No. of established ntES cell lines $(\%)$ \\
\hline TT2-ep & 86 & $36(45)$ & $4(10)$ \\
YV1-ep & 57 & $26(46)$ & $2(8)$ \\
YV1-lp & 69 & $37(54)$ & $2(5)$ \\
\hline
\end{tabular}

Table 4 Developmental ability of ntES cells after tetraploid complementation.

\begin{tabular}{|c|c|c|c|c|c|c|}
\hline Established cell line & Donor nucleus & $\begin{array}{c}\text { No. of embryos } \\
\text { transferred }\end{array}$ & $\begin{array}{c}\text { No. of newborn } \\
\text { obtained }(\%)\end{array}$ & $\begin{array}{l}\text { No. of revived } \\
\text { pups }(\%)\end{array}$ & $\begin{array}{c}\text { No. of pups } \\
\text { surviving to } \\
\text { adulthood (\%) }\end{array}$ & $\begin{array}{l}\text { No. of germline } \\
\text { transmission }(\%)\end{array}$ \\
\hline ntTT2-1 & TT2-ер & 59 & $2(3)$ & $0(0)$ & - & - \\
\hline ntTT2-2 & TT2-ер & 69 & $0(0)$ & - & - & - \\
\hline ntTT2-3 & TT2-ep & 43 & $2(5)$ & $0(0)$ & - & - \\
\hline ntTT2-4 & TT2-ер & 76 & $1(1)$ & $0(0)$ & - & - \\
\hline ntYV1-1 & YV1-lp & 98 & $1(1)$ & $0(0)$ & - & - \\
\hline ntYV1-2 & YV1-Ip & 94 & 14(15) & 11(79) & $8(73)$ & 8(100) \\
\hline ntYV1-3 & YV1-ep & 123 & $2(2)$ & $0(0)$ & - & - \\
\hline ntYV1-4 & YV1-ep & 91 & $1(1)$ & $0(0)$ & - & - \\
\hline
\end{tabular}


from them. First, we established new ntES cell lines from both ES-Ip and ES-ep cell-derived cloned blastocysts (Table 3). Recently, Blelloch et al. (2004) showed that there are strong correlations between the differentiation state of the donor nucleus and the efficiency of producing full term pups and ES cell lines after NT. However, the efficiency of the isolation of ntES cell lines ranged from 5 to $10 \%$ in our present study. On the other hand, Blelloch et al. (2004) generated ntES cell lines from ES cell with over $50 \%$ success rate. The efficiency of the isolation might influence the presence or absence of MEK inhibitor in culture condition.

When ntES cells derived from EC cells were tested for tumor or chimera formation, the resulting ntES cells displayed identical potential as their respective donor EC cells (Blelloch et al. 2004). In other words, genetic modification of EC cells was not completely reprogrammed in oocyte after NT and the characteristics of the EC cells were conveyed to the ntES cells. In the present study, the ntES cell lines derived from ES-ep cells exhibited low developmental potential to term after tetraploid complementation similar to the ability of the original ES cell lines (Table 4). These results coincide with a previous report and show that it is difficult to rescue the developmental potential of ES cells, once lost by longterm culture, via NT, because the profound epigenetic modification was not precisely reprogrammed in oocyte.

In this study, we attempted to estimate the in vivo developmental potential of ES cell by in vitro differentiation ability, because accumulated epigenetic modifications in ES cell may influence the in vitro ability. The cell lines established did not have a remarkably different in vitro differentiation ability (Fig. 4), when they were compared with original ES cell lines respectively. Suzuki et al. (1997) have shown that the in vitro differentiation ability of ES cells can be predicted from their germline contribution. This difference appears to depend on the number of ES cells at the initiation of EB formation. We have found that the ntES cell lines could be established from cloning of ES cell with ES-ep. However, profound epigenetic modifications accumulated by prolonged cultivation could not be reprogrammed via NT and ntES cells retained their low developmental potential in vivo.

\section{Acknowledgements}

The authors would like to thank T Tokunaga for providing the TT2 embryonic stem cell line. The authors declare that there is no conflict of interest that would prejudice the impartiality of this scientific work.

\section{References}

Amano T, Kato Y \& Tsunoda Y 2001 Full-term development of enucleated mouse oocytes fused with embryonic stem cells from different cell lines. Reproduction 121 729-733.

Blelloch RH, Hochedlinger K, Yamada Y, Brennan C, Kim M, Mintz B, Chin L \& Jaenisch R 2004 Nuclear cloning of embryonal carcinoma cells. PNAS 101 13985-13990.
Dean W, Bowden L, Aitchison A, Klose J, Moore T, Meneses J, Reik W \& Feil R 1998 Altered imprinted gene methylation and expression in completely ES cell derived mouse fetuses: association with aberrant phenotypes. Development 125 2273-2282.

Eggan K, Akutsu H, Loring J, Jackson-Grusby L, Klemm M, Rideout WM III, Yanagimachi R \& Jaenisch R 2001 Hybrid vigor, fetal overgrowth, and viability of mice derived by nuclear cloning and tetraploid embryo complementation. PNAS 98 6209-6214.

Fulton BP \& Whittingham DG 1978 Activation of mammalian oocytes by intracellular injection of calcium. Nature 273 149-151.

Hadjantonakis AK, Macmaster S \& Nagy A 2002 Embryonic stem cells and mice expressing different gfp variants for multiple noninvasive reporter usage within a single animal. BMC Biotechnology 211.

Humpherys D, Eggan K, Akutsu H, Hochedlinger K, Rideout WM III, Biniszkiewicz D, Biniszkiewicz D, Yanagimachi R \& Jaenisch R 2001 Epigenetic instability in ES cells and cloned mice. Science $\mathbf{2 9 3}$ 95-97.

Keller GM 1995 In vitro differentiation of embryonic stem cells. Current Opinion in Cell Biology 7 862-869.

Munsie MJ, Michalska AE, O'Brien CM, Trounson AO, Pera MF \& Mountford PS 2000 Isolation of pluripotent embryonic stem cells from reprogrammed adult mouse somatic cell nuclei. Current Biology 10 989-992.

Nagy A, Gócza E, Diaz EM, Prideaux VR, Iványi E, Markkula M \& Rossant J 1990 Embryonic stem cells alone are able to support fetal development in the mouse. Development $\mathbf{1 1 0}$ 815-821.

Nagy A, Rossant J, Nagy R, Abramow-Newerly W \& Roder J 1993 Derivation of completely cell culture-derived mice from earlypassage embryonic stem cells. PNAS 90 8424-8428.

Rideout WM III, Wakayama T, Wutz A, Eggan K, Jackson-Grusby L, Dausman J, Yanagimachi R \& Jaenisch R 2000 Generation of mice from wile-type and targeted ES cells by nuclear cloning. Nature Genetics 24 109-110.

Robertson EJ 1987 Embryo-derived stem cell lines. In Teratocarcionomas and Embryonic Stem Cells: a Practical Approach, pp 71-112. Oxford: IRL Press.

Suzuki $H$, Kamada N, Ueda $O$, Jishage $K$, Kurihara $Y$, Kurihara $H$, Terauchi Y, Azuma S, Kadowaki T, Kodama T, Yazaki Y \& Toyoda Y 1997 Germ-line contribution of embryonic stem cells in chimeric mice: Influence of karyotype and in vitro differentiation ability. Experimental Animals 46 17-23.

Tanaka M, Gertsenstein M, Rossant J \& Nagy A 1997 Mash2 acts cell autonomously in mouse spongiotrophoblast development. Developmental Biology 190 55-65.

Ueda O, Jishage K, Kamada N, Uchida S \& Suzuki H 1995 Production of mice entirely derived from embryonic stem (ES) cell with many passages by coculture of ES cells with cytochalasin B induced tetraploid embryos. Experimental Animals 44 205-210.

Wakayama T, Rodriguez I, Perry ACF, Yanagimachi R \& Mombaerts $\mathbf{P}$ 1999 Mice cloned from embryonic stem cells. PNAS 96 1498414989.

Wakayama T, Tabar V, Rodriguez I, Perry ACF, Studer L \& Mombaerts P 2001 Differentiation of embryonic stem cell lines generated from adult somatic cells by nuclear transfer. Nature 292 740-743.

Yagi T, Tokunaga T, Furuta Y, Nada S, Yoshida M, Tsukada T, Saga Y, Takeda N, Ikawa Y \& Aizawa S 1993 A novel ES cell line, TT2, with high germline-differentiating potency. Analytical Biochemistry 214 $70-76$.

Received 24 January 2006

First decision 27 February 2006

Revised manuscript received 4 April 2006

Accepted 9 May 2006 